\title{
Heroes, Hymen and Honour: A Study of the Character of Attitude Change among Male Youth with Their Roots in an Honour-Based Context
}

\author{
Devin Rexvid \\ Department of social work, Umea University \\ SE-901 87 Umea, Sweden \\ Tel: 46-90-786-9872Ｅ-mail: devin.rexvid@socw.umu.se \\ Astrid Schlytter (Corresponding author) \\ Department of Media Studies, Stockholm University \\ Box 27 861, S-115 93 Stockholm, Sweden \\ Tel: 46-8-164-502 E-mail: astrid.schlytter@jmk.su.se
}

Received: Feburary 23, 2012

Accepted: April 24, $2012 \quad$ Published: June 1, 2012

doi:10.5539/res.v4n2p22

URL: http://dx.doi.org/10.5539/res.v4n2p22

\begin{abstract}
Background: Honour-related violence and oppression (HRVO) became a public and a state concern in Sweden in the wake of murders of three young women of foreign origin in the late 90's and early 20's. The Swedish society's focus on girls' and women's exposure to honour-related restrictions and reprisals, overshadowed to some extent, boys' and young men's condition in the honour context. Yet in recent years boys' and young men's dual role as both victims and potential perpetrators in honour culture has received increasing attention in Sweden. In the discussion on how HRVO must be combated, attitude change interventions targeting boys and young men have been emphasized as an important measure.
\end{abstract}

Purpose: The overall aim of this study is to elucidate and compare the participants' attitudes towards honour, masculinity and virginity in a retrospective perspective i.e. before and after their attendance in an attitude change program.

Method: The study is based on a content analysis of individual in-depth and focus group interviews with participants and leaders of an attitude change project called "Sharaf Heroes".

Findings: This study indicates that honour-based norms and values are very persistent which requires both an uncompromising and an arduously intervention targeting attitude change.

Keywords: Honour, Heroes, Hymen, Rumours, Sharaf, Virginity, Masculinity

\section{Introduction}

\subsection{Background}

Between the years of 1996-2002 three young unmarried women of foreign descent were murdered in Sweden. What these victims had in common was that they were murdered by their male family members. The first victim was murdered by her brother and male cousin, the second by her uncles and the third by her father. What the offenders had in common, on the other hand, was their intent to restore the family honour by murdering these young women who by their "shameful behavior" had brought the family into disgrace. These three murders, in particular the murder of Fadime Sahindal, attracted much attention in the Swedish society. Thus honour-related violence and oppression (HRVO) became a public and a state concern (Ekström, 2009; Schlytter, 2004).

The debate on HRVO in Sweden focused primarily on girls' and women's exposure to HRVO. Boys' and men's conditions in the honour-related context remained more or less neglected until the first case of honour killing of 
a young Afghan man took place in Sweden in the year 2005. Since then, boys' and young men's situation in general and their dual role as both victims and potential perpetrators have received proportionately more attention. Two aspects in the discussion of boys and young men in the honour cultural context have been highlighted. The first is that it's necessary but not fully adequate to merely support and protect female victims of HRVO but in addition the community support and the social action should also be directed toward changing the attitudes of men who advocate and/or practice honour-based traditions. The second aspect emphasizes the importance of support and help to those men who are victims of HRVO (Bredal, 2011; Schlytter, Högdin, Ghadimi, Backlund \& Rexvid, 2009a).

In the wake of the murder of Fadime Sahindal in 2002, a number of NGO projects and organizations, among others a project called "Sharaf Hereos", founded in Sweden (Ekström, 2009; Schlytter, Rexvid, Celepli \& Nasih, 2011). The project has since inception been concentrated on directing attitude change intervention toward young men with their roots in the honour culture. The point of departure of this study is to scrutinize how the concept of honour as a way to legitimate control of female sexual purity is understood by male youth participating in the attitudinal change project "Sharaf Heroes" in Sweden.

\subsection{Aim and research questions}

The overall aim of this study is to elucidate and compare the participants' attitudes towards honour, masculinity and virginity in a retrospective perspective i.e. before and after their attendance in an attitude change program.

Our research questions are as follow:

- What is, according to the participants, the meaning of the concept of honour?

- What do they think of the question of women's equal rights to men?

- Who do the participants prefer as their future spouse?

- What ideas do they have of Swedish men?

\subsection{Theoretical framework}

Considering the project name "Sharaf Heroes" our theoretical point of departure is grounded in the concepts of sharaf and heroes, since both these concepts are used in an honour-based context (Peristiany \& Pitt-Rivers, 1992/2005; Wikan, 2003). Sharaf is an Arabic word for honour and is used as a masculine term for men who act in a courageous, hospitable, and peaceful or holly way to represent or defend the honour (Abu-Rabia, 2011; Abu Zeid, 1965; Peristiany \& Pitt-Rivers, 2005; Wikan, 2003). Hero is a Greek word, and means men who are defending the community's limits; these may be physical but they are also moral (Campbell, 1964).

In Arabic language there is a distinction between sharaf and 'ird or 'ard. While sharaf stands for male qualities such as courage, reliability, honesty and men's ability to protect their properties, 'ird or 'ard refers to untouched and chaste female relatives. According to the Dutch culture anthropologist van Eck (2003), there are two concepts of honour among Turks. These are namus and şeref. The first refers to sexual honour i.e. to virginity, chastity and sexual purity of the female family members. The latter concept stands for status, prestige and standing. Turkish şeref is used in an identical fashion as the Arabic Sharaf. In a similar manner the Greek concept philótimo denotes male honour, but there is speculations that there are two types of philótimo: one represents chaste related women and the other refers to the "male ego" (Safilios-Rothcild, 1964; van Eck, 2003).

Honour, as a masculine concern, stands in our use of the concept, for a norm and value systems whose cornerstone is male control of female sexuality. Masculinities denote, simply put, a set of expectations which postulate what is masculine and non-masculine. The expectations are influenced of contextual, historical and cultural factors. Those who live up to those expectations, which are contextual, historically specific and culturally entrenched, are perceived as masculine, while the rest (women, homosexuals, coloured men etc.) are excluded (Connell, 1995; Kimmel \&Aronson, 2008). Every particular historical and cultural context provides a hegemonic notion of masculinity (Connell, 1995). The hegemonic masculinity stands for "the configuration of gender practice which embodies the currently accepted answer to the problem of the legitimacy of patriarchy, which guarantees (or is taken to guarantee) the dominant position of men and the subordination of women" Connell (1995, p. 77). While hegemonic masculinity in the modern context has been de-virginized (Khan, 2006), men's expectations of their future partner's and related women's virginity is still a cornerstone of the hegemonic masculinity in the context of honour culture (Schlytter et al., 2009a; Khan, 2006).

Both honour and masculinity are relational concepts in the sense that we can make sense of them only when we relate them to their opposites. In the case of honour the opposite is disgrace or dishonour and not shame as some 
authors contend (Wikan, 2003). When it is coming to masculinity the opposite consists primarily of femininity and homosexuality (Connell, 1995; Kimmel \& Aronson, 2008).

The central theoretical perspective of our analysis concerns honour as a system of norms and values whose cornerstone is composed on various ways of controlling the female body, sexuality, conduct and recreation (Cindoglu, 1997; Commaraswamy, 2005; Gilligan, 1997; Khan, 2006; Parla, 2001; Safilios-Rothcild, 1964; Sen, 2005). Honour consists of two parts; one is the purity of women, the other the renown of the name of the family (Tillion, 1966/2007; Di Bella, 1992/2005). Sons have a specific role because they have a position both in the feminine "inside" world and the masculine "outside" world (Di Bella, 1992/2005). According to the French anthropologist Germaine Tillion (1966/2006) boys learn to control their sisters because they have to guard the status of theirs fathers and grandfathers. Honour is the basis for the economical and social existence of the family. Sons inherit the honour which means that they have to defend the name of the family but also the continuance of the family (Tillion, 1966/2007; Di Bella, 1992/2005). They have to give proof of their courage and their ability to defend their point of honour, to show that they are worthy of their family's name. When they are older, they have to show evidence of their capacity to lead their familial group with the sagacity and prestige of their father (Di Bella, 1992/2005).

Honour-related values, first of all the value of female sexual purity, can be deeply rooted in young men, also for those living in a modern society like Sweden as long as the family they are grown up in practice honour-based norms and values. Two studies conducted of the authors indicate that young males in the context of honour culture possess a double role (Schlytter et al., 2009a, Schlytter, Högdin \& Rexvid, 2009b). The double role implies that the young males can be considered as victims as well as potential perpetrators. According to these studies boys and young males as well as girls and young females with immigrant background have restrictions when it comes to the question of the choice of future spouse (Schlytter et al., 2009b). About $11 \%$ of all the youth, who is fifteen years old, are obliged to follow what their parents decide and this is more common for the young female than for young male, $13 \%$ respectively $9 \%$. Among the females about $80 \%$ have both parents born abroad, for the young males the same is $60 \%$. The results of our survey show that almost $20 \%$ of the females and $13 \%$ of the males aged 16-25 years in some suburb areas with high immigrant population have similar restrictions (Schlytter et al., 2009b). Other aspect of the situation for boys and young males is that they have to control their sisters, female cousins and sometimes also their mothers. Some boys and young males are themselves controlled by members of the family (Schlytter et al., 2009a).

Regarding the other central concept in our theoretical framework i.e. the concept of "hero", the project "Sharaf Heroes" is not only an arena for young men to change their attitudes towards honour-related norms and values. It also affords the participants the possibility to describe which values they are supposed to be defended after being a "Sharaf Hero"? This means that the project is an arena for young men to define the concept of honour in the context of a modern individualistic society (Wainryb \&Turiel, 1994; Kağıtçıbaşı, 2002, 2007; Mernissi 1982; Bauböck 1996). This is a transformation from how the concept is used in traditional, hierarchically, collectivistic societies where the individual's situation is determined by her place in the social network to how it can be defined in an individualistic society based on individual autonomy and individual rights as the Swedish society. Collectivism and individualism are about the relationships between individuals in a group and refers to the way in which people perceive themselves in relation to other members of society (Wainryb \&Turiel, 1994; Kağıtçıbaşı, 2002, 2007; Mernissi, 1982; Shulruf, Hattie \& Dixon, 2011). As we mentioned above, honour is a masculine concern that has a decisive influence on the ranking of men. According to the French sociologist Pierre Bourdieau (1990) masculinity is a male habitus that is constructed and accomplished in the space that is reserved for men. This is a space for competition among men, and these competitions are strengthening the cohesion among men (Meuser, 2007). Women are the audience. They are according to Bourdieau the "flattering mirrors" which reflect and confirm the men's self image (1990, p. 26). A central aspect in our analysis of the participants' answers is therefore: what are the positive and negative aspects of masculinity in the traditional and the modern world, and how do they view gender relations?

\section{Method}

\subsection{The context of the study}

The target group of the project "Sharaf Heroes" is boys and young males of foreign background with their "roots" in an honour-based context aged 16-25 and living in the suburbs of major Swedish Cities. The aim of the project "Sharaf Heroes" is to change these young males' attitudes towards honour- related norms and values.

The project organizes dialogues and educations with the intention to influence ingrained attitudes. The project consists of several different parts; two essential parts are recruitment and education. The project reaches young 
people primarily through schools. After talking about HRVO as a violation of human rights, they start a dialogue process with the male youth who have shown interest in the project. Interested persons are invited to a few dialogue sessions held in the project's premises. Those who show an eager interest and a serious commitment to the objectives of the project are offered to participate in the Sharaf-education. Under the period of six years (2003-2008) 63 young men have been trained and certified as Heroes. They have participated in discussions, lectures and other activities, which for most of them means that they have been a part of the project at least six months. The education package consists of eight lectures and the main themes are Human Rights, sexuality, virginity, gender equality and different forms of discrimination. Before attending the sharaf-education the young males are invited to have dialogues with the project leaders, as a preparation for the education. After accomplished sharaf-education the participants can be a part of the team who visits schools, both to introduce discussions on the theme honour-related values and norms and to recruit new "Sharaf Heroes". Groups of "Sharaf Heroes" have established in four areas in Sweden, mainly metropolitan cities.

The project has been evaluated twice, first in 2006 (Schlytter \& Kanakura, 2006) and last time in 2008 (Schlytter et al., 2011). The project is financed by the Swedish state, The State Inheritance Fund, and it is on the behalf of this fund that we have made the evaluations. Both evaluations are based on interviews with the participants, the leaders of "Sharaf Heroes" and assessments of documents and reports produced by the project. In the first evaluation all participants, 16 young males, in the two on-going sharaf-groups participated. Two years later we conducted a follow-up evaluation. The last evaluation was based on 2 focus groups and 3 individual interviews, in total 15 respondents (aged 16-25 year) were involved. The participants in both evaluations were of foreign background which means that they themselves were born abroad or had foreign-born parents. More specifically they had their origin in Middle East, Africa and Latin America. Adhering to ethical principles of the Swedish Central ethical review board (http://www.epn.se/en/start/startpage/) we cannot disclose more specific information about the respondents' heritage which can reveal their identity. A focus group is defined as a form of group discussion in which participants in interaction with each other communicate perspectives on a given subject. This communicated perspective can be impossible to grasp in other ways. Focus groups were chosen as data collection method to capture the participants 'collective image of masculinity, honour, innocence and sex life, etc. (Billinger, 2005).

The participants in the last evaluation belonged to two groups in two metropolitan areas; these were the two on-going groups in the project at that period. The sample represented half of the participants in one of the groups and almost all participants in the other one. The interviewees were recruited through an agreement with the leaders of these two groups. The leaders would ensure that as many participants as possible would attend the two interview occasions. The interviews were based on a thematic interview guide. The themes were: honour, masculinity, virginity and choice of future spouse. The interviewees were provided information about consent and confidentiality. All interviews were conducted in the premises of the project. All interviews were recorded and transcribed verbatim. Quotations in this study are entirely derived from the interviews on the last evaluation.

Furthermore this article is based on a content analysis of the participants' accounts of changes in their attitudes toward masculinity, honour and virginity. Content analysis is described as an established method for rigorous analysis of the information, content and themes in written or symbolic material, such as interview excerpts. We read the entire interview excerpts to familiarize ourselves with the content of respondents' reasoning and statements. The theme-based interview guide facilitated the coding of the interviews and theme-based common patterns in respondents' statements. Large meaning units were then condensed to concise and illustrative meaning units in accordance with the themes in the interview guide i.e. honour, masculinity, virginity and choice of future spouse (Neuendorf, 2002; Granheim \& Lundman, 2004).

\section{Results}

\subsection{Participants' views on honour}

In this section we discuss the participants' views on and definition of honour. This is built on the interviewees' reasoning concerning their ideas of honour before they get involved in the project. The results indicate that several of the interviewees had been socialized into the honour culture as part of their family's code of behaviour. Yet, even before joining "Sharaf Heroes", some of these young men had begun to question these values.

The honour culture's norms and values are the central focus of the sharaf-education, which brings up the matter of human rights and shows how oppression and violence in the name of honour are crimes against these rights. Furthermore the education is problematizing the concept of honour itself, pointing out that oppression and violence are an intrinsic side of honour culture norms and values. The participants talk about two different 
dimensions of the concept of honour. One dimension is related to negative associations and that concerns women's fertility. Some of the participants (PA) described honour in this manner:

PA1:"For me honour was my sister, my mother, my female cousins. My sister was not allowed to have a boyfriend, and my mother was not allowed leave the house without the veil".

PA2: "Honour means that there is no rumour about my family and people do not talk badly about my sisters. It was like that, stuff like that stood for honour to me. [...] People who come from that kind of patriarchal cultures they see honour as it has to do with the female members of the family".

The other dimension of the concept of honour was according to several participants to be honest, show respect for others, and appreciate others and to be grateful. Other key-words that they used were altruism, kindness, self-respect, respect for others, pride in oneself, steadfastness in pursuing own goals, being true to their values and defending them. The respondents put the positive dimension of honour in following terms:

PA3: For me honour is to be a good person, to be honest, to show respect for others, appreciate others, to be grateful. That's what I think that honour is".

PA4: "A person who cares about and helping another human being, a person who is not evil, doesn't have evil thoughts about others, an honest person, a person who does not want anyone else any harm".

Regarding the relationship between the two dimensions of the honour concept, most of the participants look at the negative dimension as "a black spot". This spot is distinct, constitutes a minor part of the honour culture and it is possible to erase it. This understanding of honour as two separate parts, of which only one is concerning women's fertility, seems to have had a great impact on the participants.

Another aspect, even though a problematic one of the two-dimensional concept of honour, according to a number of the interviewees, is that the majority society largely has a negative view of the honour concept, associating it largely with honour killing. This negative conception can, according to the participants only serve to confirm the preconceived notion among Swedes of immigrants as being (potential) honour killers or that honour killing is something solely existing among immigrants. This is probably one of the reasons why some respondents favour a positive concept of honour.

PA5: "Well, all Swedes I've asked have said that honour means prestige, respect, status and honesty. What are these for? They are only positive things but when they write about honour, it's just negative things and this is just bullshit, what they write".

To sum up, the participants' discussion has resulted in an understanding of honour as having two conceptions, a positive and a negative one, and their conclusion is that it is important to keep and actively defend the positive dimension.

3.1.1 Does the new positive honour concept include women?

The new positive concept of honour can be interpreted as a part of the human right tradition. Keywords as kindness and altruism have the same essence as the foundations of the human rights (Nussbaum, 2002). An important question is therefore, if the participants recognize women equal to men? Are girls and women including? Does the positive concept have a universal aspect?

This proved to be a difficult question to answer. On the one hand, the participants believed that women and man should have equal rights; on the other hand a majority of them recognized the concept of honour, in its positive sense, as a masculine characteristic. This is a contradiction since the outcome of the answer that only men possess honour, is that men and women belong to two different categories. And if only men are regarded trustworthy and altruistic, then this raises the question if women need to be represented by men. Women cannot by themselves be trustworthy. One respondent puts women's untrustworthiness in following manner:

PA6: "[...] No matter which girl you're talking about, if she has slept with at least twenty guys, when you first meet her, most of them try to describe themselves as angels. If you ask them have you had sex? No! Girls are lying thus easily whether they have had sex or not".

This is a participatory variant of masculinity which men embody in order to live up to each other's expectations and thus maintain the honour-borne masculine order. Honesty and dependability appear thus to be two exclusive male qualities.

\subsection{The hymen and choice of a future partner}

An essential theme in the sharaf-education is to dispel the myth of the hymen. Participants learn the biology of the female internal sexual organs and understand that the idea of the "maidenhead" as a covering membrane that 
literally must be penetrated is completely wrong. Since the hymen does not exist in reality, it cannot be used as a proof to reveal a woman's virginity. The participants received this knowledge as vital and none question the biological facts. The question is rather what this knowledge means for their values and their choice of a future partner. In the context of honour culture, the idea of a "maidenhead" is not only a bodily boundary, but also, as described in the theoretical section above, serves as a limitation on girls' room for action, being used to control their social and sexual behaviour.

Any participant believing that it is necessary to marry a virgin, therefore, is at the same time defending the norms and values of the honour culture and confirming its denial of girls' right to their own bodies and their sexuality. Starting from the participants' attitudes to choice of a future partner, two quite different views of girls' right to their own bodies and sexuality emerge. One group considered that choice of a future mate should be based on love and that girls as much as boys are entitled to have sex before marriage. The majority of respondents in this group seem to have held this view for a longer time and only needed the information about the nonexistent hymen to strengthen their belief. Of decisive importance for their choice is being in love and individual qualities such as personality, education and mutual understanding. Several respondents in this group also emphasize that it is unfair to place the virginity requirement on women alone when the men are allowed to have premarital sexual experiences. Following quotation shows the importance of gossips and girls' immaculate reputation.

PA7:"Immigrant men, like me, prefer that the girl is a perfect girl, you know. That she is not talking to other guys, doesn't go to disco, that she has not had any relationship with any guy. I want her perfect so that people will not talk shit about her".

PA8: "The thing is like this: if I'll be honest, there will sound wrong but I prefer a girl who has not had it before" [sexual intercourse].

PA9: "A girl who has had sex with other guys? No! I don't want everyone talking shit about me or my wife, who she has slept with and who she has had sex with. I don't think it will be fun".

PA10: "It is difficult to know [whether the girl is virgin or not]. Who should you believe, her or rumours? But if you know, it's a different story. [...] But I would rather have a virgin".

PA7: "So for me, there's no virginity. It is about whether people have had sex or not. It's about rumors and not virginity. If the rumours didn't exist virginity wouldn't either exist".

On the other hand there are those who want to marry a virgin, and for these the non-existence of a hymen leads to a number of challenges. The consequence of possessing knowledge of a no-existent hymen as a tool to prove virginity means that it is not possible for the individual male to be insured that he is marrying a virgin. Upon their first act of sexual intercourse there is no hymen to 'burst' and she will in all probability not bleed. His choice is then either to take her word for it or to find other ways of assuring himself of her chastity. One of these other ways may be to consider her general behaviour, which often takes place in combination with getting confirmation from someone in her environment. In the matter of taking her at her word, the participants in general argued as a fact that it was well-known that a woman in the context of honour culture as a matter of course could not and would not divulge her pre- and extramarital relations to a partner. Since it involves great shame to be exposed as non-virgin, this is something no woman in the honour-related context would dare to confess to. This means, all in all, from their point of view it is not possible to take a woman at her word, that is, rely upon her to reveal the truth about herself.

This becomes even more problematic if the woman's word goes against her reputation; if she claims to be a virgin but non-virgin according to gossips. If in that situation he does not distance himself from her, as demanded in the honour code, he may himself be considered a person of poor judgment. In this reasoning, reputation will play the decisive role. And reputation rests entirely on the idea that a girl may not have premarital sexual relations, but must remain chaste and untouched for her husband. The effect of gossip is thus the same as the myth of the "maidenhead". The risk of rumour is what puts limitations on the behaviour of young women and determines what her social standing is to be. Reputation is something external to the young female and includes the men in her closest family. This means that rumour (reputation) plays a double role, controlling both the woman and the man. On account of this, it is in the interests of the man to control the women in his family so that they do not get bad reputations. In other words, the threat of a bad reputation legitimizes men's control of women. A good man is thus a man who not only has a reputation untarnished by the behaviour of female family members, but who also can see to it that these women never give cause for doubt. In consequence, his masculinity is to a great extent dependent on his ability to control his women. These reasoning shows how difficult, not to say impossible, it is to break away from the honour culture. 


\subsection{Conceptions of masculinity before and after contact with Sharaf Heroes}

The participants state that before coming into contact with "Sharaf Heroes" they had associated manliness with the man as breadwinner of the family, a head of the household who is physically and mentally strong and authoritarian. Now, after accomplished sharaf-education, they give another meaning to the concept. Manliness is now related to independence, respect, honesty, dependability and helpfulness. The participants' description of masculinity is here identical with their definition of honour as the right of the individual to respect and to be treated with civility by people around him. Respect, in this sense, is something to be earned and to win.

In some of the participants' reasoning about respect it is clear that a real man is the one who treats people with respect and is treated in a respectful way. Of the keywords for manliness that the participants mention, namely independence, respect, honesty, dependability and helpfulness, respect appears to be the one considered most important. Some respondent illuminate different masculine qualities in following terms:

PA11: "I have always heard from my father and my uncles that a man is the one who takes care of his wife and children. But now I have learned new things i.e. a man is strong, independent, helpful, not selfish, generous, and he's doing something for the society".

PA12: "A real man is the one who is honest and respectful, a very grateful person. If we make a generalization, he should be the kind that is most outwardly oriented. He'll be the one who has everything under control, if we make a generalization".

In line with this, the participants discuss the connection between respect and femininity; how should one characterize a woman who shows respect for others and who is also treated with respect? From this discussion two different viewpoints emerge. One is that a real woman should have other qualities than respect/respectability; the other that masculinity is a form of humanity in the same way that femininity is, in other words, that respect is a quality common to all people. Here several participants point out that through the education they had learned to replace masculinity by humanity. One respondent articulate the gender bias of respectability in following fashion:

PA13: "A real man? Most people think that if you are strong and have respect for others, then you're a real man. If you respect other people, you will get respect in return. That's what I call manliness".

Interviewer: A woman can as well show respect for other persons. Do think that she exhibits a masculine behaviour in doing so?

PA14: "I don't think that her behaviour is masculine; it has rather to do with her personality".

\subsection{The participants' attitudes to ethnic Swedish men}

Another way of capturing the interviewees' conceptions of what it is to be a man was to let them describe their notions about ethnic Swedish men.

The relation of men to women is apparently a clear marker with which some of the participants draw a line between ethnic Swedish men and men of foreign background. Foreign men are considered to have a need to control their family and closely related females, part of which is to ensure that his female relatives maintain a good reputation by avoiding been seen in the wrong places, such as discotheques, and by being forced to stay away from men they are not acquainted with.

Swedish men, on the other hand, are depicted by participants as being democratic and on an equal footing in relation to family, wife and children, at the same time as they discriminate against men of foreign decent and feel superior to them. According to several interviewees, there are two vital factors that explain the difference between men of Swedish and foreign background. These are socialization and the context in which the socialization has taken place. It is important whether the men have grown up in a democratic or in a totalitarian setting. The respondents' contextualization of the concept of masculinity is manifest in these excerpts.

PA15: "Swedish men are, in comparison with immigrant men, more calm and as they have had a different upbringing, they behave in a completely different way i.e. in a more peaceful and pedagogical way. Immigrant men who come from authoritarian and patriarchal systems do exhibit a relatively more aggressive behaviour and want to exercise power all the time".

PA13: "I will say one thing. Thus, immigrant men, they like to have more control over the family thus over the woman. And Swedish men may even be beaten by their women. It is a trivial thing".

On an overall level the participants find that native Swedish men and men of foreign background stand for different views of the female, the one group having an equal and the other a clearly hierarchical relationship. At 
the same time, in their relationships with men of foreign background, Swedish men revert to the hierarchical. This relationship of superiority-inferiority is most clearly visible on the labour market. An example of this on the individual level is the man of foreign background who has equivalent merits or sometimes even better qualifications than a Swedish man but is nevertheless degraded to take such unqualified jobs as taxi driver or pizza baker. One participant explains this behaviour as an expression of the inherent racism of which foreign men routinely are the victims.

PA5: "And the other thing is that Swedish men always have the important jobs. [...] Where do you see a Swedish man working at a pizzeria, drive a cab? Do you understand what I mean? We get the dirty works. Which Muhammad is a lawyer? No one! That is why we have the right to say that they are very racist. They are not racists but they hate us".

In summary, participants describe the Swedish society as hierarchical, although not in the relationship between women and men but rather in the relationship between ethnic Swedish men and men of foreign background.

There were, however, other participants who had another view of ethnic Swedish men. These participants wished to gain all the possibilities offered by the Swedish society, such as in the matter of easier communication and patterns of social behaviour between the sexes which enables men and women to get to know each other and to form a more realistic opinion of each other before they enter into a partnership.

Clearly, the participants derived their reasoning from two quite different conceptions of what it is to be a man, through contrasting an autonomous masculinity with a heteronymous/dependent prototype. In the first category, the good name and standing of the man is entirely divorced from the woman's behaviour. The opposite is true for men who belong to the second category.

The respondents mention a few similarities between men of Swedish and foreign background. These similarities mean that both groups tend to overestimate their masculinity. Furthermore men in general are also supposed to be in need to appear tough and stand out in the crowd.

\section{Discussion}

The discussion begins with a description of the participants' oscillation between maintenance of and distancing from the virginity standards. We will subsequently outline a conceivable consequence of the demystification of the ancient myth of the "maidenhead" for the masculine identity. The article ends with a reflection on young men's dual role as both victims and presumptive perpetrators in the context of honour culture.

\subsection{The participants' mental journey between complicity and deprecation}

The aim of the project Sharaf Hereos was to change the participants' attitudes towards the value of female sexual purity. This is the cornerstone in the honour-related value system and the pillar in the construction of masculinity in the honour culture. The results in this study indicate that the participants' attitudes have partly been changed regarding the very important aspects of controlling girls and women's behavior to secure their virginity. In this part the attitude appears to have been transformed from a positive value to a negative one. This is a mental change that most of the participants have undergone. When it comes to the reason why it is necessary to control girls and women - to safeguard their virginity, the participants have different views. One group requires love marriage and girls/women's self-determination when it comes to their sexuality. This group recognizes girls' equal right to premarital intimacy. Another group prefers a future partner who is "untouched" and has a good reputation. This is a very problematic view because this presupposes that there are other men who control those woman's behaviour and sexuality. The demand for "untouched" women upholds the honour-based norms concerning women's virginity and men's honour. To prefer a virgin as future spouse can be seen as an expression of a participating masculinity (cp Connell, 1995), i.e. that in this way men participate in the maintaining of virginity norms. This preference stands for a complicit manifestation of hegemonic masculinity in the honour-based context.

The value system that the participants find desirable can be found in what they perceive as the positive dimension of the honour culture. From their point of view this positive dimension stands for "honesty, altruism, kindness, self-respect, respect for others, pride in oneself, steadfastness in pursuing own goals, being true to own values and defending them". To achieve this ideal the participants need a redefinition of the honour concept. The respondents' distinction between a positive and a negative concept of honour appears to be quite fuzzy because the positive concept of honour originates from and is depended on the negative one. This means that men in honour-related contexts are dependent on control of related women's sexuality in order to maintain male honour and reputation. This emerges from the fact that there is an agreement that the new honour concept applies to men, but the view that this is not self-evident when it comes to women. Lack of agreement on these matters is also 
manifested in the views expressed in their criteria for choice of a future partner. The respondents have different opinions on whether it is love, the partner's personality and educational level that should be the decisive factors or her status as a virgin or non-virgin. In the end, this is a discourse on whether women and men have the same capacities and therefore equal value.

If the positive dimension is a value system only for men, then this value system contains a view of women that is in direct opposition to the norms embedded in this very same value system, namely by suggesting that the norms of kindness, altruism and respect for others do not apply to women but only to men. In the view of women the negative dimension of honour seems still to play a large role, in which case it is hardly a new value system. To clarify what is required in order for the positive dimension of honour to form a new value system, it is necessary to break every link to the norm and value system of honour culture, that is, what has been named the negative dimension of honour. It is consequently not enough to emphasize one side -the positive dimension- alone in order to change the content of the concept of honour.

The platform or value system preferred by the participants has, according to them, great similarities with the ideals that they associate with men from the majority society. The norms and values of the latter are considered to be far from the ones that the participants have been socialized into. The changes in attitude that have occurred are experienced by most of these young males as enormous, especially for those brought up in the honour culture with the expectation upon them of controlling closely related women, and who experience the changes as an individual "liberation". Nevertheless the majority of the participants seem to have experiences of a masculinity that they personally wish to distance themselves from and the desire to embrace new ideals.

In summary, it is possible to say that the respondents oscillate between two different value systems. Simultaneously as they reject the concept of honour in the sense of control of female sexuality (i.e. deprecation), they also ask for virgin girls (i.e. complicity, cp Connell, 1995) as future spouses. Although the respondents perceive that the hierarchical structure of society puts them in a subordinate position in relation to men from the majority society, there are several participants who do not reject the ideals and values that they consider to be characteristic of men from the mainstream society. The respondents seem to identify themselves, to some extent, with these ideals. This partial identification can be regarded as an expression of their susceptibility to influences from the hegemonic masculinity in the mainstream society. These young men are themselves striving towards a masculine behaviour that they describe as calm and egalitarian, in contrast to authoritarian and controlling; ideals that in the sharaf-education are described as the positive dimension of honour. This means that the participants do not advocate an identity that is in total contrast to the hegemonic masculinity of the majority society. It is beyond the scope of this study to speculate whether the honour-based masculinity's exposure to increased influences of the hegemonic masculinity in mainstream society weakens the respondents participation in the maintenance of honour-based norms and thus reinforces their rejection of the key value of honour culture i.e. control of female sexuality.

\subsection{Mental journey between demystification and negotiation}

In the theoretical section of this study, we described a hero as one who defends the group's physical and moral boundaries. This description of the hero concept may be inadequate in the sense that a hero is not only involved in defense of but also combating some other moral boundaries, values and norms. Put it differently a hero does not only defend his own group's boundaries from intruders but also combats the intruder's transgression of the groups" borders. In the case of "sharaf-heroes", this relationship seems to be reversed. The "sharaf-heroes" are supposed to serve outsiders (i.e. the majority society), defending the latter's borders and challenging their own group's moral boundaries. The critical question is: what are the values and limits which the "sharaf-heroes" must defend and/or fight?

The dual role of the heroes as combatants and defenders gives rise to two different sets of questions. One set relates to questions about what limits should be resisted: are there any expectations of the girl's virginity that need to be met? In that case how do the heroes defend the family's good name, reputation and position? Is it men's dependence on the close women's sexuality that has to be challenged? Is it the expectation that men should marry virgins that has to be challenged? The second set of questions relates to issues of the limits that must be defended: Is it the girl's right to her own body that needs to be defended? Is it the girl's right to respect, to choose their future spouse that has to be defended? Or is it men's right to autonomy that needs to be safeguarded?

Although it is difficult to find adequate answers to these questions the heroes dual roles indicate that the Sharaf-education is facing a great difficulty. Problematization of the "hymen", i.e. demystification of an ancient myth, does not lead automatically to the young men's breakup with honour culture's central value i.e. control of female sexuality. What seems to have occurred in the value system of several participants is a shift from their 
focus on the "hymen" (which does not exist but can be faked) as an unreliable control mechanism to a more reliable one i.e. rumors and social control of the girl's sexuality. This can be regarded as a manifestation of a kind of negotiating masculinity (Connell, 1995). Current research (Schlytter et al., 2009a) indicates how modern information technologies (IT) is used to partly substitute the function of an "intact hymen". Youth people's premarital interaction with the opposite sex can now be monitored easily through (fe)male relatives control of the youths electronic transactions via mobile phones, e-mail and various social media platforms (Schlytter et al., 2009a). The knowledge that "maidenhead" is a myth and that girls can fake virginity (Mernissi, 1982) puts youth male from honour culture in a bargaining position. Here they can need assistance in redefining their male identity, not only in relation to their female relatives, but also in relation to the woman who might be their future spouses.

\section{Conclusion}

The results of this study suggest how difficult, though not impossible, it is to change a very ancient value system through an attitude changing intervention. The respondents' oscillation between complicity (Connell, 1995) and deprecation on the one hand and the demystification and negotiation on the other hand, can be regarded as a clear manifestation of this difficulty. This oscillation can in part be related to ambiguity in the attitude influencing intervention. What the respondents perceive as two distinct aspects of honour, is in fact two mutually dependent parts of the honour-based value system. The status, respectability and honour of men in honour-related contexts are dependent on their ability to control the sexuality of closed women.

On the basis of the results we can conclude that an attitude change agenda that challenges the whole web of oppressive power relations can be more likely to bring about equality and liberty. Such an attitude change agenda has two tracks. The one is focused on the equal value of human-beings in the sense that girls have the same capacities and abilities as boys, so that honour norms confine girls to an inhuman life. The other track is focused on the conditions of boys in the honour culture, where it is urgent to unequivocally show how honour norms circumscribe and restrict their freedom and life conditions, in as much as it is expected of them to oppress and punish closely related women's "improper behaviour". In this respect boys would not only be liberating their closest female relatives but also themselves from a gender system that gives them both advantages (gives them superiority, social status, etc.) and disadvantages (oppression and punishment of closely related women). This is a key issue for boys/young men who are to distance themselves from the honour culture by seeing through the role of rumour and the tyranny of reputation and managing to go beyond these oppressive mechanisms. The issue, finally, for both girls and boys, and which should be their common agenda, is freedom from oppression.

\section{References}

Abu-Rabia, A. (2011). Family Honor Killings: Between Custom and State Law. The Open Psychology Journal, 4, (Suppl 1-M4), 34-44. http://dx.doi.org/10.2174/1874350101104010034

Abu-Zeid, A. (1965). Honor and shame among the Bedouin of Egypt. In Peristiany, J. (Ed.), Honor and shame (pp. 256-257). London: Weidenfeld and Nicolson.

Baglia, J. (2005). The Viagra Ad Venture: Masculinity, Media and the Performance of Sexual Health. New York: Peter Lang Publishing.

Bredal, A. (2011). Mellom makt og avmakt. Om unge menn, tvangsekteskap, vold og kontroll. ISF Rapport (2011:004). Oslo: Institutt for samfunnsforskning.

Bauböck, R. (1996). Social and Cultural Integration in a Civil Society. In Bauböck, R., Heller, A., \& Zolberg, A. (Eds.), The Challenge of Diversity. Integration and Pluralism in Societies of immigration. Aldershot: Avebury.

Billinger, K. (2005). Fokusgrupper- en datainsamlingsmetod. Lund: Studentlitteratur.

Campbell, J. K. (1964). Honour, family and patronage: A study of institutions and moral values in a Greek mountain community. Oxford: Clarendon Press.

Cindoglu, D. (1997). Virginity Tests and Artificial Virginity in Modern Turkish Medicine. Women's Studies International Forum, 20(2), 253-261. http://dx.doi.org/10.1016/S0277-5395(96)00096-9

Connell, R. (1995). Masculinities (2 ed.). Cambridge: Polity Press.

Coomaraswamy, R. (2005). Violence against women and 'crimes of honour'. In Welchman, L. \& Hossain, S. (Eds.), 'Honour' Crimes, paradigms, and violence against women. Zed Books, London.

Di Bella, M. P. (1992/2005). Name blood and miracles: the claims to renown in traditional Sicily. In Peristiany, J. G. \& Pitt-Rivers, J. (Eds.), Honor and grace in anthropology. Cambridge: University Press.

Ekström, S. (2009). Hedersmorden och orden: berättelser om kultur, kritik och skillnad. Stockholm: Makadam. 
Gilligan, J. (1997). Violence: reflections on the National Epidemic. New York: Vintage Books.

Graneheim, U. H., \& Lundman, B. (2004). Qualitative content analysis in nursing research: concepts, procedures and measures to achieve trustworthiness. Nurse Education Today, 24, 105-112. http://dx.doi.org/10.1016/j.nedt. 2003.10.001

Kağıtçıbaşı, C. (2002). Cross-cultural Perspectives on Family Change. In Liljeström, R., \& Özdalga, E. (Eds.), Autonomy and Dependence in the Family, Turkey and Sweden in critical perspective. Swedish research institute in Istanbul.

Kağıtçıbaşı, C. (2007). Family, Self and Human Development Across Cultures. Theory and Applications. Lawrence Erlbaum Associates, Inc., Publishers: New Jersey.

Khan, T. S. (2006). Beyond Honour. A Historical Materialist Explanation of Honour Related Violence. New York: Oxford University Press.

Kimmel, M. S., \& Aronson, A. (red.) (2008). The gendered society reader (3 ed.). New York: Oxford University Press.

Mernissi, F. (1982). Virginity and patriarchy. Women's Studies International Forum, 5(2), 183-191. http://dx.doi.org/10.1016/0277-5395(82)90026-7

Meuser, M. (2007). Serious Games: Competition and the homosocial construction of masculinity. Norma 1, Universitetsforlaget, Norge. [Online] Available: http://www.nordiska.uu.se/digitalAssets/66/66164_meuser. pdf

Neuendorf, K. A. (2002). The content analysis guidebook. Thousand Oaks, CA: Sage Publications.

Nussbaum, C. M. (2002). Kvinnors liv och social rättvisa. Ett försvar för universella värden. Göteborg: Daidalos.

Parla, A. (2001). The "honor" of the state: virginity examinations in Turkey. Feminist studies, 27(1). http://dx.doi.org/10.2307/3178449

Peristiany, J. G., \& Pitt-Rivers, J. (Eds.). (1996/2005). Honor and grace in anthropology. Cambridge: University Press.

Safilios-Rothcild, C. (1969). "Honour" Crimes in Contemporary Greece. The British Journal of Sociology, 20(2), 205-218. http://dx.doi.org/10.2307/588531

Sen, P. (2005). Crimes of honour', value and meaning. In L. Welchman \& S. Hossain (Eds.), 'Honour' Crimes, paradigms, and violence against women. Zed Books, London.

Schlytter, A. (2004). Rätten att själv få välja: arrangerade äktenskap. kön och socialt arbete. Lund: Studentlitteratur.

Schlytter, A., \& Kanakura, L. (2006). Elektra - Ett projekt mot hedersförtryck och våld. Stockholm: Allmänna Arvsfonden.

Schlytter, A., Högdin, S., Ghadimi, M., Backlund, A., \& Rexvid, D. (2009a). Oskuld och heder. En undersökning av flickor och pojkar som lever under hedersrelaterad kontroll i Stockholm stad-omfattning och karaktär. Stockholm stad.

Schlytter, A., Högdin, S., \& Rexvid, D. (2009b). Rätten att själv få välja vem man ska gifta sig med kartläggning bland unga i årskurs 9 i Stockholms stad. i Gift mot sin vilja. Ungdomsstyrelsens skrifter, 2009:5.

Schlytter, A., Rexvid, D., Celepli, Ö., \& Nasih, B. (2011). Heder och det civila samhällets metoder. Stockholm: Allmänna Arvsfonden.

Shulruf, B., Hattie, J., \& Dixon, R. (2011). Intertwinement of individualist and collectivist attributes and responses sets. The Journal of Social, Evolutionary, and Cultural Psychology, 5(1), 51-65. [Online] Available: http://137.140.1.71/jsec/articles/volume5/issue1/ShulrufVol5Iss1.pdf

Tillion, G. (1966/2007). My Cousin, My Husband. Clans and Kinship in Mediterranean Societies, Saqi Essentials, London.

van Eck, C. (2003). Purified by blood. Honour Killings amongs Turks in the Netherlands. Amsterdam: Amsterdam University Press.

Wainryb, C., \& Turiel, E. (1994). Dominance, Subordination, and Concepts of Personal Entitlements in Cultural Contexts. Child development, 65(6), 1701-1722. http://dx.doi.org/10.2307/1131289

Wikan, U. (2003). En fråga om heder. Stockholm: Ordfront. 